\title{
Investigation of Karst Morphology in the Subsurface of Kinta Valley Using the Gravity Method
}

\author{
${ }^{1}$ Abd Rahim Harun \& ${ }^{2}$ Abdul Rahim Samsudin \\ ${ }^{1}$ Jabatan Mineral Dan Geosains Malaysia \\ ${ }^{2}$ Program Geologi, Pusat Pengajian Sains Sekitaran dan Sumber Alam \\ Fakulti Sains dan Teknologi \\ Universiti Kebangsaan Malaysia.43600, Bangi, Malaysia. \\ 'arh@jmg.gov.my \& ${ }^{2}$ abrahim@pkrisc.cc.ukm.my
}

\begin{abstract}
A regional gravity survey had been carried out in Kinta Valley, Perak in June 2009 and February 2010. The study area located between latitude line of $4^{\circ} 18^{\prime} 8.4^{\prime \prime} \mathrm{N}$ and $4^{\circ} 44^{\prime} 04^{\prime \prime} \mathrm{N}$ and longitude line of $100^{\circ} 55^{\prime} 03^{\prime \prime} \mathrm{E}$ and $101^{\circ} 57^{\prime} 55.8^{\prime} \mathrm{E}$. The valley situated at the centre between the peninsular main range at the western part and Kledang Hill in the east. A total of 372 gravity stations had been measured using the Scintrex CG-5 gravity meter, with stations interval range between $0.5-2$ kilometre. The Tiernan-Wallace altimeter was use to determine the height of every stations. The reduction process had been done using the software "Magnetic and Gravity Reduction" (MREDUC), and then been gridded, filtered and analysed using the Oasis Montaj (Geosoft) software.

The gravity survey in Kinta Valley, Perak successfully delineated the difference lithological boundary in the subsurface due to fault in regional scale. A total of 20 anomalies due to karstic morphology in the subsurface such as depressions and pinacles were clearly delineated. From the total horizontal derivative map done for regional and the residual map the gravity survey successfully delineated many lineament structures due to tectonic activity in the subsurface at depth and shallow part respectively.
\end{abstract}

